\title{
ESTIMATION OF DURABILITY AND DEFORMATION PROPERTIES OF CONCRETE AND REINFORCED CONCRETE
}

\author{
${ }^{1}$ Rogovyi S.I., Doctor of Engineering, Professor, \\ rsi1@ukr.net, ORCID: 0000-0002-9431-5884 \\ ${ }^{1}$ Tsyhanenko L.A., PhD in Engineering sciences, Associate Professor, \\ tsyganenkola@ukr.net, ORCID: 0000-0002-6628-3635 \\ ${ }^{1}$ Sribniak N.M., PhD in Engineering sciences, Associate Professor, \\ nataliya.sribnyak.17@gmail.com, ORCID: 0000-0003-3205-433X \\ ${ }^{1}$ Lutskovskyi V.M., PhD in Engineering sciences, Senior Lecturer, \\ v.lutskovskyi@gmail.com, ORCID: 0000-0003-0230-1029 \\ ${ }^{1}$ Tsyhanenko H.M., Senior Lecturer, \\ tsyganenkogm@gmail.com, ORCID: 0000-0002-3335-4804 \\ ${ }^{1}$ Sumy National Agrarian University \\ st. Gerasima Kondratyev, 160, Sumy, Ukraine, 40021
}

\begin{abstract}
The research deals with the main directions of the Reinforced Concrete Theory current improvement on the basis of its incisive analysis. As leading direction in solving such a problem, the modern, well known deformational analytic model is examined. It is implemented on the base of complete experimental diagrams of deformation of different structural materials. The offered methods for improvement of such model suggest the creation and use of the transformed diagrams of deformation of concrete, reinforced elements as well as those structural elements on their basis. The modelling of these diagrams is envisaged on the basis of experimental dependences of complete diagrams for deformation of construction materials taking into account the influence on them of different physical, technological, dynamic and other factors. The general view of the said diagram will be realized by two its branches - ascending and descending, designed by different parametric (key) points. The special interest on the modern stage in development of deformational analytic model presents the design of descending branch of complete diagram on the state of construction material that is recorded by different parametric points.

One of the main tasks in designing of such points is standardization of experimental methods in determining the critical values of relative power deformations in the top of a diagram, that correspond to the limit straining of construction material, that does not exceed the board of its durability at a compression. The descending branch of complete diagrams must be designed on condition that the deformation of concrete became consistently waning. The transitional point of this state in sustained and increasing deformation it to be considered as destruction start of material at intensively increasing destructive transformations of its structure. The straining of constructional material on such on-loading area of diagram can diminish to the level of postcritical values, beyond the durability range of stability at a compression, and to correspond to relative deformations in the limit state. Further reduction in tension to the concrete is representative at its dynamic deformation in terms of more intensive development of destructive transformations. Thus the level of relative deformations can increase to the maximally possible values, beyond which a concrete, as structural material, stops to comply with the necessary operating qualities.

The long-term experience in initiation, perfection and development of theory of the reinforced concrete, as well as implementation of its modern deformational model of calculation show that there is a number of important vital problems which need to be examined and solved for today. Such problems in the outlined aspect are to be examined in two directions of researches. The first is an improvement of methodology of tests and standardization of methods in obtaining the complete experimental diagrams of the state and their parametrical points which allow to design dependence $\sigma_{b}-\varepsilon_{b}$ (straining - deformation) with high authenticity by the analytical function for its implementation at the calculations of different structural elements; the second is an improvement of
\end{abstract}


deformational calculation model with help of the transformed diagrams of deformation, as well as more precise definition of some pre-conditions and positions accepted in different existent standards for the calculation of concrete and reinforce-concrete constructions. The essence in solving of the above-said pressing issues set forth in this research.

Keywords: concrete, reinforced concrete, reinforcement structures, strength, deformability, transformed diagram.

Problem definition and analysis of existing solutions. The main method for calculation of concrete and reinforced concrete structures is nowadays the deformational analytic model; it is adopted in most regulatory documents of various countries. In the context of the implementation of the program of transition to the Euro codes, such a model is accepted as the main method of the theory in calculation of concrete and reinforced concrete in Ukraine [1]. The implementation of this analytic model is carried out according to the well-known procedure of the classical method for calculating concrete and reinforced concrete structures. In this case, complete diagrams of deformation of concrete and reinforcement are used, covering both elastic and inelastic work of materials.

The stage of development and improvement of the deformational analytic model, which is implemented in various regulatory documents, should certainly be considered as the next progressive step towards the improvement and implementation of the further regulatory framework in the theory of reinforced concrete. However, a critical analysis of the existing provisions in creation and development of such a theory justifies the need for its improvement on the basis of a deformational analytic model, implemented using complete experimental deformational (state) diagrams of concrete.

Analysis of recent research. As evidenced by numerous studies by various authors [2], the creation of a modern analytic model for assessing the strength and deformation properties of concrete and reinforced concrete should be based on the method of reliable analysis of nonlinear deformation and stress conditions of materials. At present, the interest of researchers is noticeably increased and they are extensively studying the possibility of creating a deformational analytic model of the force resistance and deformation of concrete and reinforced concrete based on complete real diagrams in deformation of materials. This model allows a new approach to the assessment of the strength and deformational characteristics of various structural materials.

Among the most important problems in the theory of calculating the strength and deformability of concrete and reinforced concrete elements the fundamental one is the study of deformations, taking into account nonlinear analysis and destructive processes occurring at different loading levels, including the stage close to destruction. A significant amount of research carried out in this field of inquiry, the accumulated experience in the design and operation of structures determine the need and the possibility of creating a new, systematic definition and solution of problems in the theory of reinforced concrete.

Such problems can be solved by means of analytic models for concrete, reinforced concrete, and similar reinforced structural elements under different force actions: central and eccentric (at any eccentricities) compression and bending - the equations of mechanical condition [3, 4], which constitutes the basis of modern modelling of strength resistance into various structural materials. This equation makes it possible to obtain more reliable results in comparison with the calculating methods used in practice. An important advantage of this approach is that it eliminates the need to apply a number of empirical dependencies used in various normative methods.

The currently used deformational model of calculation, which is applied in various regulatory documents, allows the calculation of the most common types of reinforced concrete structures according to a simplified schematic. At the same time, on the basis of the deformational analytic model that exists today, numerous developments have been created to calculate the strength of various structural elements under the action of various types of forces. At the same time, it should be noted that developments in this area have not yet reached the required level so that they can be adopted as normative calculation methods. Therefore, such calculations, adopted as various

Bulletin of Odessa State Academy of Civil Engineering and Architecture, 2021, no. 84, page 49-58 
regulatory documents, are implemented with a number of additions and improvements that would allow a more universal approach to the calculation.

One reason for eliminating the noted shortcomings and for improving the deformational analytic model of concrete and reinforced concrete that exists today can be considered the study and implementation of various transformed diagrams of various structural materials state. Such diagrams are modelled on the basis of experimental dependences of the parameters of the corresponding structural material $\sigma_{m}-\varepsilon_{m}$ (stresses - deformations), taking into account the influence of various physical, technological, strain and other factors.

The purpose of the research. To perform a critical analysis of nonlinear deformational models for assessing the strength and deformability of concrete, reinforcement, and similar reinforced structural elements, highlighting the positive and negative aspects of such models. On the basis of a comparative analysis, to outline and implement methods for improving various deformational calculation models, both for the upgrading the methods in obtaining complete experimental deformation diagrams, and for modelling various transformed deformational diagrams of various structural elements.

Research technique. From a large number of classifications in research methods, those were selected that allow obtaining good convergence of the accepted abstract models, assumptions and calculation results obtained on their basis - with the data obtained from empirical studies. At the same time, the task was to achieve reliable data on the said results of studies of the strength and deformability of structural materials.

Research results. The build-up of a generalized analytical dependence $\sigma_{b}-\varepsilon_{b}$ between stresses and deformations of concrete is one of the key problems in the theory of reinforced concrete, which is also of multifaceted scientific and practical interest [5]. This dependence makes it possible to objectively assess the stress-strain condition of concrete and reinforced concrete, uniformly and inhomogeneously deformed sections of structural elements at different loading levels, including the limit one. That said, it becomes possible to take into account the nonlinearity of the deformation of concrete and reinforcement, which most closely corresponds to the physical essence of assessing the force resistance to deformation and destruction of such materials.

Considering the complete deformational diagram as a generalized dependence $\sigma_{b}-\varepsilon_{b}$, it can be described as a result of the approximation of the corresponding experimental diagrams obtained during tests with a controlled (artificially or naturally) deformation mode. In well-known published works [6] such dependences are modelled by many authors in the form of two parts: ascending and descending (Fig. 1). There is a significant amount of experimental data that make it possible to fairly reliably simulate the ascending branch of such a diagram, but the situation with the representation of its descending part is somewhat more complicated [7].

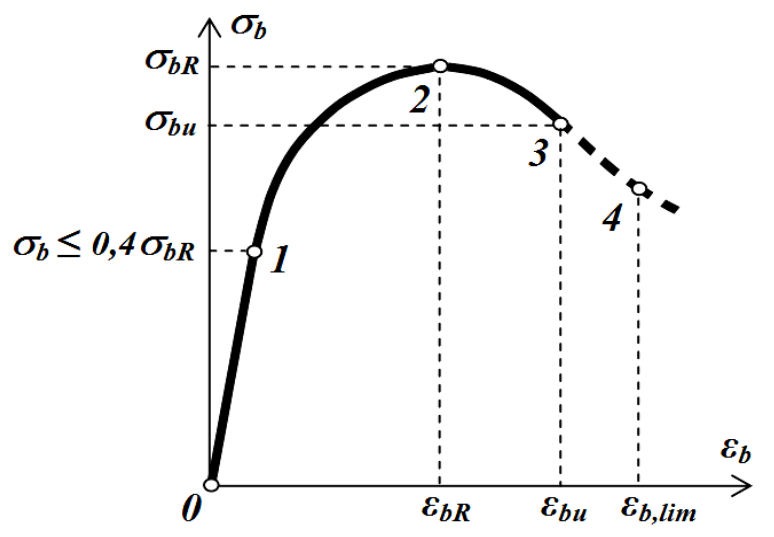

Fig. 1. The complete diagram of concrete deformation $\sigma_{b}-\varepsilon_{b}$, represented by its main components: $0 \ldots 1$ - linear section; 1 ... 2 - section of elastoplastic deformations; 2 ... 3 -descending section of overcritical deformations; $3 \ldots 4$-descending section of maximum allowable deformations $\varepsilon_{b, \lim }$ 
As for the representation of this dependence in the ascending section, at present, a fairly extensive experimental data has been accumulated, and there are also separate theoretical generalizations that make it possible to fairly simulate this part of the diagram. In this case, one can proceed from the following reliably established facts. Deformation of concrete, which has a heterogeneous structure with numerous defects, is accompanied by destructive processes that contribute to the development of existing defects, as well as the appearance and development of new structural damages. Such processes start at relatively low levels of concrete stresses and they further progress as their level rises, up to the limit state $[8,9,10]$.

Thus, in the ascending section, the $\sigma_{b}-\varepsilon_{b}$ diagram can be represented by intermediate critical points characterizing the level of stresses and the level of destructive processes in the structure of concrete, associated with its level of loading. Intermediate critical points 1 and 2 (there can be a lot of them) are shown in the diagram (Fig. 1). There are certain difficulties in simulating the descending section. One of them is the inconsistency of some data on the deformability of concrete, obtained in the experiments of different authors [11]. There are also different interpretations of the concepts and physical essence of some parametric points of this part of the diagram [12], in particular, the concept of "limiting deformation".

Considering the descending section of the $\sigma_{b}-\varepsilon_{b}$ diagram, several critical values of the deformability of concrete should be distinguished. One of these values at the onset of the descending section $\varepsilon_{b R}$ - the ultimate compressibility of concrete, which corresponds to the achievement of its strength $R_{b}$. It should be noted that this is the common point of the ascending and descending parts of the diagram or the top of the $\sigma_{b}-\varepsilon_{b}$ curve. There are different empirical forms of approximation of the parameter $\varepsilon_{b R}$, which provides close magnitudes of this value, depending on the strength, the nature of concrete, the rate of its deformation, the duration of the load, etc. [13, 14,]. The end point of the complete $\sigma_{b}-\varepsilon_{b}$ diagram can be fixed by different parameters depending on the type of such diagram and its purpose $[15,7]$.

The concrete stress in this section of the diagram can decrease to the level of supercritical values $\sigma_{b u}<R_{b}$, corresponding to deformations in the limiting state $\varepsilon_{b u}$. A further decrease in concrete stresses (under deformations $\varepsilon_{b}>\varepsilon_{b u}$ ) is characterized by its deformation on the condition of more intensive development of destructive transformations. In this case, the level of deformations $\varepsilon_{b}$ can increase to the maximum possible values $\varepsilon_{b . l i m}$ [16], beyond which concrete, as a material, ceases to meet the necessary performance characteristics, such as water absorption, associated frost resistance, anti-corrosion protective properties, etc.

The effect of reinforcement on the deformability of concrete with a sufficiently large amount of it (percentage of reinforcement) can be very significant and take place at different loading levels, including the limiting one. At the same time occurs the relaxation of stresses and their redistribution onto the reinforcement, which is more efficiently engaged in the work with further considerable increase of stresses. Effecting in this way the work of concrete, the reinforcement can significantly reduce the rate of its deformation and significantly increase the deformability of the reinforced section. Such regularities of deformation have been reliably established by practical considerations in many studies. At the same time, a significant number of experiments have been carried out; the empirical dependences are proposed to assess the deformability of sections depending on the ratio of reinforcement and some other parameters.

The essence of various problems also lies in the fact that the transformation of the dependences $\sigma_{b}-\varepsilon_{b}$ is carried out in most cases by unreasonable limitation of the descending branch by some average statistical value of the limit deformation and reduced strength of concrete at the end of the complete diagram. At the same time, some authors also unreasonably consider as acceptable the premise of a decrease in the limit deformations of concrete with the increase in its durability; and such deformation is considered as a certain constant of the material. If we judge by the reliable, experimentally established fact, according to which the nature of the descending branch, in particular its length, is in large part depending on the rate of deformation, then it is easy to substantiate the following. Changing the deformation rate for the exactly similar concretes, we can get different limit deformability at the end of the $\sigma_{b}-\varepsilon_{b}$ diagram.

Bulletin of Odessa State Academy of Civil Engineering and Architecture, 2021, no. 84, page 49-58 
Thus, it becomes necessary to restrict the complete transformed diagram by some critical deformation which corresponds to the limiting state of the element, which would limit the area of stable deformation of the $\sigma_{b}-\varepsilon_{b}$ dependence. Only such a transformed diagram can be used to simulate the stress-strain state of inhomogeneously compressed concrete and uniformly compressed reinforced concrete elements, acting as a general equation of the mechanical state of concrete and reinforced concrete. One of the problems solved in this research is the creation of a model of such a transformed diagram.

In what follows, we mean two varieties of complete deformational diagrams $\sigma_{b}-\varepsilon_{b}$. The first, the reference, were obtained when testing reference specimens under reference test mode for a uniformly deformed concrete section; the second, the transformed, were obtained by transforming the corresponding parametric points of the reference diagram for the given initial parameters of the structural element. Such transformed diagrams are designed to simulate the nature of deformation of any other bar elements and any other type of deformation that differs from the reference one. A distinctive feature of the transformed diagrams is the fact that the deformations $\varepsilon_{b R}$ at the peak of the $\sigma_{b}-\varepsilon_{b}$ curve may not be critical. For such diagrams the critical are the deformations $\varepsilon_{b u}$, which fix on the complete transformed diagram the end point of stable deformation, as well as the limiting state of the section, while limiting the descending branch of such a diagram by the parametric point $\varepsilon_{b u} \geq \varepsilon_{b R}$ and the corresponding ultimate strength of concrete $R_{b u} \leq R_{b}$.

The researchers show an increased interest in the study of the complete transformed $\sigma_{b}-\varepsilon_{b}$ diagram for a rather long time. At the same time, a significant amount of experimental material has been accumulated that allows an approximate description of such a diagram, and it is already implemented nowadays in various design standards in some countries. However, as noted $\mathrm{Mr}$. Gvozdev A.A. and Mr. Baikov V.N., the data, given in these sources, are not enough for specific calculations. A number of issues related to the build-up of physical and analytical model of such a transformed diagram require clarification and additional research.

The transformed diagram of the concrete deformation in the descending section can be fixed by parametric points, corresponding to the $\varepsilon_{b R}$ deformation and the aforementioned critical $\varepsilon_{b u}$, as well as by the law of change in the residual strength of concrete $R_{b u}$, corresponding to the deformation $\varepsilon_{b u}$. For different cases, the values of such a critical deformation at the end of the diagram can vary within significant limits and are determined by a combination of a number of factors: the nature of the stress-strain state, the physical and mechanical characteristics of sections of concrete and reinforcement.

Within uniform (axial) compression of concrete sections, with the achievement of $\varepsilon_{b R}$, deformation, corresponding to stresses $R_{b}$, a further increase in the uniform deformations of concrete over the entire section will lead to decrease in the stresses in it, and hence the load bearing ability. Consequently, for such cases, the critical deformations of the section, that fix its limiting state, are determined by the equality $\varepsilon_{b R}=\varepsilon_{b u}$. For uniformly compressed reinforced concrete, as well as for heterogeneously compressed concrete and reinforced concrete sections, in which reinforcement with critical deformations $\varepsilon_{s u}>\varepsilon_{b R}$, is used, the following conditions must be met: $\varepsilon_{b R}<\varepsilon_{b u} \leq \varepsilon_{b, \max }$ (here $\varepsilon_{s u}$ is the critical deformation of the reinforcement, corresponding to its limiting state).

At above-average levels of loading onto such elements, stress redistributions in sections are observed: in non-uniformly compressed concrete - from more deformed to less deformed fibers of the section; in reinforced concrete, uniformly and inhomogeneously compressed - also from concrete to reinforcement. The maximum values $\sigma_{b}=R_{b}$ of inhomogeneous plot of concrete stresses, in the process of deformation, will shift from the extreme, most deformed fibers, depthward of the inhomogeneously compressed section, approaching the neutral axis. Such fibers will operate according to the law of the descending branch of the $\sigma_{b}-\varepsilon_{b}$ curve, while undergoing significant deformations, accompanied by destructive transformations of the concrete structure, up to destruction. 
It should be assumed for a uniformly compressed reinforced concrete section, that in all uniformly deformed concrete fibers the stresses can reach maximum values $R_{b}$, and the reinforcement may not be fully used. With a further increase of the load, the stresses in the reinforcement of such sections can increase; in the concrete operating according to the law of the descending branch of the $\sigma_{b}-\varepsilon_{b}$ diagram, they can slightly decrease. The limiting state of such a uniformly deformed section occurs upon reaching the critical deformation of concrete $\varepsilon_{b u}$ and stresses in the section, corresponding to its residual strength $R_{b u}$.

Definition of the concept of "critical deformation". For a long time, using the term "limit deformation" in scientific sources, different authors put different concepts into it. In some cases, it means the ultimate compressibility of concrete under axial compression; in others, it means the deformation of the edge fiber of an inhomogeneously deformed section; and sometimes this term means the greatest deformation, recorded at the end of tests at the stage preceding destruction. All these concepts have been widely used and are still used in the theory of reinforced concrete to this day. For some authors common for all these definitions is the fact that all the meanings of the named limit deformations are considered as some constants of the material that determine its deformability when the strength become exhausted.

In fact, all of the above deformations, immediately preceding destruction, for the same concrete can change significantly under the influence of a number of conditions. Thus, if we set the problem of finding the limiting deformations as some constant of the material, which is implied in some scientific sources, - such a statement will not be correct. It should also be noted that the use of a uniform term "limiting deformation" for all of the above cases is far from always justified.

To identify the objective laws of concrete deformation, it is necessary to use the concept of "critical deformation"; upon reaching it there will be a qualitative leap or the transition of quantitative changes in the accumulation of deformations and structural changes into qualitative ones. This refers to the change in the structure of concrete during force deformation, investigated by Mr.Berg O.Y. Such critical values of deformations, determining the level of stresses and the level of destructive changes in the material, associated with the level of loading and the level of force deformation, will determine the strength as well as the performance of concrete.

Calculation of critical deformations. The values of such deformations will be found based on the nature of the complete diagram of concrete deformation, taking into account the descending branch (Fig. 1), where these values (points $1 \ldots$ 4) are presented as general functions and act as some parametric points, generalizing the results of different experiments and fixing the descending branch of the complete deformational diagram. Such a diagram can be transformed by establishing the values of such functions for any accepted initial parameters of a concrete and reinforced concrete element, any loading conditions; and present a complete transformed diagram for use in theoretical studies, numerical experiments and engineering calculations. The degree of reliability of the study and description, the allowances made for the influence of the variety of various factors that determine the parametric points of the transformed diagrams, will determine the reliability of such a deformational diagram.

In many research works, various authors present conflicting points of view regarding the determination of this value, emphasizing the importance of studies of the ultimate compressibility of concrete under axial compression and considering its dependence on the strength of concrete. The essence of these contradictions lies, for example, in the fact that, according to some $\boldsymbol{\varepsilon}_{\boldsymbol{b} \boldsymbol{R}}$ increases with increasing concrete strength, while others, on the contrary, believe that it decreases. As you know, such conflicting judgments have existed for quite a long time.

However, there are other points of view on these issues, for example, [17] and others, where it is recommended to find deformations at the top of the curve depending on the strength of concrete. It is also assumed that other factors can have a very significant effect on the value of $\varepsilon_{b R}$ : the type of concrete, its composition, process conditions, as well as the loading mode, which should be taken into account when determining this value. In this regard, large-scale studies should be carried out, the purpose of which is to reliably establish the influence of various factors on the key parameters of the complete deformational diagrams of structural materials.

Bulletin of Odessa State Academy of Civil Engineering and Architecture, 2021, no. 84, page 49-58 


\section{Conclusions:}

1. Considering various aspects of the improvement and development of a nonlinear deformational model of calculation, it can be argued that it is the most general, corresponding to the real operating conditions of structures, accurate and promising in comparison with other methods of calculation used today.

2. Such a model allows one to abandon a number of empirical dependencies; it also objectively simulates and evaluates the stress-strain state of various structural elements, which will ultimately contribute to the possibility of calculating and designing of buildings and structures more reliably and economically.

3. The existing experience of creating and improving the deformational model of calculation, based on complete deformation diagrams, shows that in this direction it is necessary to solve a number of important problems, such as:

- improvement and standardization of research methods relating to complete experimental diagrams of concrete state, which allow to reliably simulate the dependence $\sigma_{b}-\varepsilon_{b}$ by an analytical function for its implementation in the calculations of various elements of building structures;

- improvement of the analytic deformational model, based on transformed diagrams of the state of concrete, reinforcement and various other composite elements of reinforcement of structures, taking into account various physical, mechanical and other factors that are not reflected in previously known analytic models;

- clarification of some of the prerequisites adopted in various existing norms for the calculation of concrete and reinforced concrete structures; first of all, we mean the essence and definition of key parametric points of the ascending and descending branches of diagrams simulating the analytical $\sigma_{b}-\varepsilon_{b}$ dependences.

4. The noted lines of research are closely related to each other, and their implementation as a single set can become the basis for further improvement of the theory of reinforced concrete, which should be based on an experimental basis and reliably simulate the stress-strain state, strength and reliability of various structural elements of buildings and structures.

\section{References}

[1] DSTU BV.2.6-156:2010. Betonnye i zhelezobetonnye konstrukcii iz tyazhelogo betona. Pravila proektirovaniya. K.: Ministerstvo regional'nogo razvitiya i stroitel'stva Ukrainy, 2011.

[2] S.I. Rogovoj, Nelinejnoe deformirovanie $v$ teorii zhelezobetona $i$ raschet prochnosti normal'nyh sechenij : monografiya. Poltava, RVVPNTU, 2002.

[3] V.M. Bondarenko, S.V. Bondarenko, Inzhenernye metody nelinejnoj teorii zhelezobetona. M.: Strojizdat, 1982.

[4] V.G. Nazarenko, "Diagramma deformirovaniya betona s uchetom nispadayushchej vetvi", Beton i zhelezobeton, no. 2, pp. 18-22, 1999.

[5] S.I. Rogovoj, "K postroeniyu obobshchennoj modeli polnoj diagrammy deformirovaniya betona", Resursoekonomni materiali, konstrukciï, budivli ta sporudi. Zb. nauk. pr., vip. 6, pp. 94-104, 2001.

[6] A.I. Zvezdov, A.S. Zalesov, T.A Muhamediev, E.A. CHistyakov, "O novyh normah proektirovaniya zhelezobetonnyh i betonnyh konstrukcij", Beton i zhelezobeton, no. 2, pp. 2-6, 2002.

[7] S.I. Rogovoj, "K utochneniyu nekotoryh opredelenij i harakternyh tochek polnoj diagrammy deformirovaniya betona pri szhatii", Izv. Vuzov. Str-vo, no. 11, pp. 119-122, 2000.

[8] O.YA Berg, Vysokoprochnyj beton. M.: Strojizdat, 1971.

[9] V.YA. Bachinskij, A.N. Bambura, S.S. Vatagin, "Svyaz' mezhdu napryazheniyami i deformaciyami betona pri kratkovremennom neodnorodnom szhatii", Beton i zhelezobeton, no. 10, pp. 18-19, 1987. 
[10] O.YA. Berg, Fizicheskie osnovy teorii prochnosti betona $i$ zhelezobetona. M.: Gosstrojizdat, 1961.

[11] S.I. Rogoviy, "Pro neuzgodzhenIst deyakih danih doslIdzhennya deformativnostI stisnenogo betonu", Galuzeve mashinobuduvannya, budIvnitstvo, vip. 5, pp. 113-117, 2000.

[12] S.I. Rogovoj, "Obosnovanie sushchnosti opredeleniya kriticheskih deformacij betona i polnaya diagramma ego deformirovaniya s uchetom niskhodyashchej vetvi", Resursoekonomni materiali, konstrukciï, budivli ta sporudi, vip. 5, pp. 245-252, 2000.

[13] A.R. Nelepov, "Analiz metodik po opredeleniyu maksimal'nyh deformacij betona szhatoj zony sterzhnevyh elementov", Izv. vuzov. Str-vo, no. 1, pp. 126-130, 1999.

[14] V.G. Nazarenko, "Diagramma deformirovaniya betona s uchetom nispadayushchej vetvi", Beton i zhelezobeton, no. 2, pp. 18-22, 1999.

[15] S.I. Rogovoj, "Predel'nye deformacii betona pri odnorodnom i neodnorodnom szhatii", Beton i zhelezobeton v Ukraine, no. 1, pp. 14-16, 2000.

[16] E.A. Bocharova, A.N. Gibalenko, S.I. Rogovoj, "Sovershenstvovanie nelinejnoj raschetnoj modeli zhelezobetona" Zb. nauk. pr. Ukraïns'kogo institutu stalevih konstrukcij im. V.M. SHimanovs'kogo, vip. 23, pp. 91-109, 2019.

[17] L. Taerve, Codes and Regulations Utilisation of High Strength. High Performance Concrete. 4-th Int. Sump. Paris, 1996. P. 93-100.

\title{
ОЦІНКА ХАРАКТЕРИСТИК МЦЦОСТІ ТА ДЕФОРМАТИВНОСТІ БЕТОНУ Й ЗАЛІЗОБЕТОНУ
}

\author{
${ }^{1}$ Роговий С.I., д.т.Н., професор, \\ rsi1@ukr.net, ORCID: 0000-0002-9431-5884 \\ ${ }^{1}$ Циганенко Л.А., к.т.н., доцент, \\ tsyganenkola@ukr.net, ORCID: 0000-0002-6628-3635 \\ ${ }^{1}$ Срібняк Н.М., к.т.н., доцент, \\ nataliya.sribnyak.17@gmail.com, ORCID: 0000-0003-3205-433X \\ ${ }^{1}$ Луцьковський В.M., к.т.Н., старший викладач, \\ v.lutskovskyi@gmail.com, ORCID: 0000-0003-0230-1029 \\ ${ }^{1}$ Циганенко Г.М., старший викладач, \\ tsyganenkogm@gmail.com, ORCID: 0000-0002-3335-4804 \\ ${ }^{1}$ Сумський начіональний аграрний університет \\ вул. Герасима Кондратьєва, 160, м. Суми, Україна , 40021
}

Анотація. На основі критичного аналізу розвитку теорії залізобетону визначено головні напрями iï сучасного удосконалення. Як провідний напрям вирішення такої проблеми розглядається досить відома на сьогодні деформаційна розрахункова модель. Вона реалізується на базі повних експериментальних діаграм деформування різних конструктивних матеріалів. Запропоновано способи поліпшення такої моделі шляхом створення і використання трансформованих діаграм деформування бетонних, армованих, а також на їх основі посилених конструктивних елементів. Моделювання цих діаграм передбачається на основі експериментальних залежностей повних діаграм деформування конструкційних матеріалів з урахуванням впливу на них різних фізичних, технологічних, силових і інших чинників. Загальний вигляд подібної діаграми реалізується двома їі гілками - висхідною і низхідною, модельованими різними параметричними (ключовими) точками. Особливий інтерес на сучасному етапі розвитку деформаційної розрахункової моделі представляє моделювання низхідної гілки повної діаграми стану конструкційного матеріалу, що фіксується різними параметричними точками.

Одна 3 головних задач моделювання таких точок - це стандартизація експериментальних способів визначення критичних значень відносних силових деформацій у вершині діаграми, що відповідають граничним напруженням конструкційного матеріалу, які

Bulletin of Odessa State Academy of Civil Engineering and Architecture, 2021, no. 84, page 49-58 
не перевищують межі його міцності при стисненні. Низхідна гілка повних діаграм повинна моделюватися за умов стало затухаючого деформування бетону. Момент переходу цього стану в незатухаюче і наростаюче деформування слід розглядати як початок руйнування матеріалу при інтенсивно наростаючих деструктивних перетвореннях його структури. Напруження конструкційного матеріалу на такій ділянці діаграми під навантаженням можуть зменшуватися до рівня їх закритичних значень, нижчих від межі його міцності при стисненні, та відповідати відносним деформаціям у граничному стані. Подальше зменшення напруження бетону $\epsilon$ характерним при його силовому деформуванні за умов більш інтенсивного розвитку деструктивних перетворень. При цьому рівень відносних деформацій може збільшуватися до максимально можливих значень, за межами яких бетон, як конструктивний матеріал, перестає задовольняти необхідним експлуатаційним якостям.

Багаторічний досвід створення, вдосконалення і розвитку теорії залізобетону, а також впровадження його сучасної деформаційної моделі розрахунку показують, що існує ряд важливих насущних проблем, які потрібно вивчати і вирішувати на сьогоднішній день. Такі проблеми в окресленому аспекті слід розглядати за двома напрямами досліджень: перший удосконалення методики випробувань i стандартизації способів отримання повних експериментальних діаграм стану та їх параметричних точок, що дозволяють 3 високою достовірністю моделювати залежність $\sigma_{b}-\varepsilon_{b}$ (напруження - деформації) аналітичної функцією для ii реалізації при розрахунках різних конструктивних елементів; другий удосконалення деформаційної розрахункової моделі 3 використанням трансформованих діаграм деформування, а також уточнення деяких передумов і положень, прийнятих в різних існуючих стандартах для розрахунку бетонних і залізобетонних конструкцій. У даному дослідженні розглядається сутність вирішення названих актуальних проблем.

Ключові слова: бетон, залізобетон, конструкції підсилень, міцність, деформативність, трансформована діаграма.

\title{
ОЦЕНКА ПРОЧНОСТНЫХ И ДЕФОРМАЦИОННЫХ СВОЙСТВ БЕТОНА И ЖЕЛЕЗОБЕТОНА
}

\author{
${ }^{1}$ Роговой С.И., д.т.н., профессор, \\ rsi1@ukr.net, ORCID: 0000-0002-9431-5884 \\ ${ }^{1}$ Цыганенко Л.А., к.Т.н., доцент, \\ tsyganenkola@ukr.net, ORCID: 0000-0002-6628-3635 \\ ${ }^{1}$ Срибняк Н.Н., к.Т.Н., доцент, \\ nataliya.sribnyak.17@gmail.com, ORCID: 0000-0003-3205-433X \\ ${ }^{1}$ Луцьковський В.M., к.Т.Н., старший преподаватель \\ v.lutskovskyi@gmail.com, ORCID: 0000-0003-0230-1029 \\ ${ }^{1}$ Цыганенко Г.М., старший преподаватель \\ tsyganenkogm@gmail.com, ORCID: 0000-0002-3335-4804 \\ ${ }^{1}$ Сумский национальный аграрный университет \\ ул. Герасима Кондратьева, 160, г. Сумы, Украина , 40021
}

\begin{abstract}
Аннотация. На основе критического анализа развития теории железобетона определены главные направления ее современного усовершенствования. Как ведущее направление решения такой проблемы рассматривается известная на сегодня деформационная расчетная модель. Она реализуется на базе полных экспериментальных диаграмм деформирования разных конструктивных материалов. Предложены способы улучшения такой модели путем создания и использования трансформируемых диаграмм деформирования бетонных, армированных, а также на их основе усиленных конструктивных элементов. Моделирование этих диаграмм предусматривается на основе экспериментальных зависимостей полных диаграмм деформирования конструкционных материалов с учетом
\end{abstract}


влияния на них разных физических, технологических, силовых и других факторов. Общий вид подобной диаграммы реализуется двумя ее ветвями - восходящей и нисходящей, моделируемыми разными параметрическими (ключевыми) точками. Особенный интерес на современном этапе развития деформационной расчетной модели представляет моделирование нисходящей ветви полной диаграммы состояния конструкционного материала, которая фиксируется различными параметрическими точками.

Одна из главных задач моделирования таких точек - это стандартизация экспериментальных способов определения критических значений относительных силовых деформаций в вершине диаграммы, которые отвечают предельным напряжениям конструкционного материала, которые не превышают границе его прочности при сжатии. Нисходящая ветвь полных диаграмм должна моделироваться при условиях стабильно затухающего деформирования бетона. Момент перехода этого состояния в незатухающее и нарастающее деформирование следует рассматривать как начало разрушения материала при интенсивно нарастающих деструктивных преобразованиях его структуры. Напряжения конструкционного материала на таком участке диаграммы под нагрузкой могут уменьшаться до уровня их критичных значений, более низких от границы его прочности при сжатии и отвечать относительным деформациям в предельном состоянии. Последующее уменьшение напряжения бетона характерно при его силовом деформировании в условиях более интенсивного развития деструктивных преобразований. Уровень относительных деформаций при этом может увеличиваться до максимально возможных значений, за пределами которых бетон, как конструкционный материал, перестает удовлетворять необходимым эксплуатационным качествам.

Многолетний опыт создания, совершенствования и развития теории железобетона, а также внедрение ее в современную деформационную модель расчета показывает, что существует ряд важных насущных проблем, которые нужно изучать и решать на сегодняшний день. Такие проблемы в очерченном аспекте следует рассматривать за двумя направлениями исследований: это совершенствование методики испытаний и стандартизация способов получения полных экспериментальных диаграмм, а так же совершенствование деформационной расчетной модели с уточнением некоторых предпосылок и положений различных существующих стандартов по расчету железобетонных конструкций.

Ключевые слова: бетон, железобетон, конструкции усиления, прочность, деформативность, трансформированная диаграмма.

Стаття надійшла до редакції 2.09.2021 